\title{
PEMERIKSAAN KESEHATAN MENUJU LANSIA SEHAT DAN BUGAR
}

\author{
Margareta Haiti ${ }^{1}$, Novita Anggraini ${ }^{1}$, Mustika Sari ${ }^{1 *}$, Lidwina Septie ${ }^{1}$,Aprida Manurung ${ }^{1}$, \\ Petronela Sihotang ${ }^{1}$, Oktasari ${ }^{1}$, Dewi Rindi ${ }^{1}$, Yohana Arvera ${ }^{1}$ \\ ${ }^{1}$ Fakultas Ilmu Kesehatan Universitas Katolik Musi Charitas \\ Email: mustikasarihutabarat33@gmail.com
}

\begin{abstract}
ABSTRAK
Kegiatan pengabdian kepada masyarakat khususnya di bidang kesehatan merupakan kegiatan yang perlu dilakukan secara berkala terutama bagi para usia lanjut (lansia) untuk menskrining Penyakit Tidak Menular (PTM). Kegiaan ini bertujuan meningkatkan status kesehatan para lansia melalui pemantauan tekanan darah dan kolesnterol, memberikan motivasi untuk melakukan aktivitas fisik sehingga diharapkan mengurangi perilaku sedentary yang dapat memicu terjadinya sindrom metabolik yang rentan terjadi pada lansia. Kegiatan pemeriksaan dan penyuluhan ini dilakukan kepada 31 orang lansia di Rumah Panti Jompo Werdha Sumarah Sukamoro Kota Palembang. Sebagai hasilnya diperoeh 17 (orang dengan kadar koesterol norma ( $<200 \mathrm{mg} / \mathrm{dL}), 23$ orang $(76.6 \%)$ dengan hasil pemeriksaan kolesterol diatas nilai normal (>200 mg/dL). Maka dari hasi ini dapat dilihat bahwa rata-rata warga panti jompoh memiliki faktor resiko hiperkolesterol, oleh karena itu diharapkan warga panti jompo dapat mengubah pola hidup yang dimulai dari pola makan dan mengatur aktivitas fisik secara teratur seperti mulai rutin melakukan jalan kaki serta aktivitas fisik lainnya untuk mencegah terjadinya komplikasi penyakit generatif.
\end{abstract}

Kata kunci: lansia, hiperkolesterol, kolesterol, pengabdian

\section{HEALTH EXAMINATION TOWARDS HEALTHY AND FIT ELDERLY}

\section{ABSTRACK}

Community service activities, especially in the health sector, are activities that need to be carried out regularly, especially for the elderly (seniors) to screen for Non-Communicable Diseases (PTM). This activity aims to improve the health status of the elderly through monitoring blood pressure and cholesterol, motivation to do a physical activity so that it is expected to reduce sedentary behavior which can trigger metabolic syndrome which is prone to occur in the elderly. This examination and counseling activity was carried out for 31 elderly people at the Sumarah Sukamoro Nursing Home for the Elderly in Palembang City. As a result, 17 people (people with normal cholesterol levels ( $<200 \mathrm{mg} / \mathrm{dL}$ ), 23 people (76.6\%) had cholesterol tests above normal values (> $200 \mathrm{mg} / \mathrm{dL}$ ). Nursing homes have risk factors for hypercholesterolemia, therefore it is hoped that residents of nursing homes can change their lifestyle, starting from diet and regulating regular physical activity such as starting to regularly walk and other physical activities to prevent complications of generative diseases.

Keyword : Elderly,cholesterol, hypercholesterolemia, community service

\section{PENDAHULUAN}

Departemen Kesehatan RI menyatakan lanjut usia adalah proses alami yang terjadi pada individu laki-laki dan perempuan berusia 60 tahun ke atas (Nuraeni, Akbar and Tresnasari, 2019). Lansia adalah seseorang yang telah mencapai usia 60 tahun ke atas. Menua bukanlah suatu penyakit, tetapi merupakan proses yang berangsur-angsur mengakibatkan perubahan kumulatif, merupakan proses menurunnya daya tahan tubuh dalam menghadapi rangsangan dari dalam dan luar tubuh (Ferdiansyah, 2016). Proses menua atau lanjut usia merupakan sesuatu yang fisiologis dengan bertambahnya umur seseoarang. Lanjut usia ditandai dengan adanya kemunduran biologis yang terlihat sebagai gejala-gejala kemunduran fisik, diantaranya kulit mulai mengendur, timbul keriput, rambut beruban, gigi mulai tanggal, pendengaran dan penglihatan berkurang, mudah lelah, gerakan menjadi lamban, dan kurang lincah. 
Dengan bertambahnya umur, fungsi fisiologis mengalami penurunan akibat proses penuaan sehingga penyakit tidak menular (PTM) banyak muncul pada lanjut usia. Selain itu masalah degeneratif menurunkan daya tahan tubuh sehingga rentan terkena infeksi penyakit menular. Hasil Riskesdas 2013, penyakit terbanyak pada lanjut usia adalah Penyakit Tidak Menular (PTM) antara lain hipertensi, artris, stroke, Penyakit Paru Obstrukf Kronik (PPOK) dan Diabetes Mellitus (DM) (Kementerian Kesehatan RI, 2016).

Berdasarkan persentase faktor risiko PTM di Puskesmas di Indonesia tahun 2015-2016 kasus hiperkolesterolemia merupakan penyakit tidak menular yang paling tinggi sebanyak 55,4\% dimana persentase kolesterol tinggi di Indonesia menurut umur sebagian besar pada kelompok umur >60 tahun sebanyak 58,7\%. Persentase tertinggi sebanyak 70\% di Papua sedangkan di Sumatera Selatan sebanyak 24,5\%. Kadar kolesterol yang tinggi (hiperkolesterolemia) menjadi salah satu indikator aterosklerosis pada pembuluh darah yang salah satunya dapat menyebabkan jantung koroner dan strok

Kolesterol berperan penting terhadap fungsi tubuh sehari-hari. Tubuh menggunakan kolesterol untuk membuat garam empedu yang membantu usus menyerap lemak. Fungsi kolesterol adalah sebagai zat esensial untuk membran sel tubuh, bahan pokok pembentukan garam empedu yang sangat diperlukan untuk pencernaan makanan, dan bahan baku untuk pembentukan hormon steroid, seperti progesteron dan estrogen pada wanita, testosteron pada pria, membuat vitamin D, dan memastika sistem pencernaan bekerja dengan baik (Solikin and Muradi, 2020).

Darah mengandung $80 \%$ kolesterol yang secara normal diproduksi oleh tubuh dalam jumlah yang tepat dan $20 \%$ berasal dari makanan. Kolesterol yang ada di dalam darah berikatan dengan protein dan ditransporasi ke seluruh tubuh. Oleh karena itu kolesterol sanat penting bagi tubuh, namun bila kadr koleterol dalam darah berlebihan berbahaya bagi kesehatan (Botham and Mayes, 2006). Kadar kolesterol normal sekitar 140-200 mg/dL dan dikatakan kadar koleterol tinggi jika mencapai 200-400 mg/dL (Balai Informasi Teknologi LIPI, 2009).

Meningkatnya jumlah kolesterol dalam darah dapat disebabkan asupan makanan yang didapat dari organ binatang, terutama otak, kuning telur dan jeroan sedangkan bahan makanan yang bersumber dari tumbuh-tumbuhan tidak mengandung kolesterol (Botham and Mayes, 2009). Bahan makanan yang mempengaruhi kadar HDL adalah asupan serat, dan gorengan. Asupan serat larut (soluble fiber) terdapat pada buah-buahan, sayuran, kacang-kacangan, biji-bijian, bulir utuh, dan oats dapat membantu menaikkan HDL darah. Minyak jelantah memiliki ikatan asam lemak jenuh dan selama proses menggoreng, minyak akan mengalami perubahan komposisi asam lemak serta kualitas minyak (Rumah, Muji and Surabaya, 2017).

Ikatan asam lemak ini sulit diurai oleh tubuh dan terbawa dalam aliran darah dan akan mengendap pada pembuluh darah di jantung dan menyumbat aliran darah, sehingga dapat mengakibatkan peningkatan kadar kolesterol total, LDL (kolesterol jahat) dan trigliserida, serta penurunan kadar HDL (kolesterol baik) dalam darah. Sedangkan dengan mengkonsumsi makanan yang mengandung kadar kolesterol tinggi beresiko meningkatkan kadar kolesterol darah atau hiperkolesterolemia (Anggraeni, 2016). 
Pengaturan metabolisme kolesterol akan berjalan normal apabila jumlah kolesterol dalam darah mencukupi kebutuhan dan tidak melebihi jumlah normal yang dibutuhkan. Namun pada orang yang lansia proses pengaturan metabolisme itu menurun sehingga dapat menyebabkan terjadinya gangguan pada regulasi asam lemak yang akan meningkatkan kadar trigliserida dan ester kolesteril (Sarasawati, 2020).

Hal ini sesuai dengan yang telah dijelaskan diatas, bahwa sebagian besar hiperkolesterolemia terjadi pada usia lanjut. Berdasarkan penjelasan inilah maka kegiatan pengabdian kepada masyarakt ini dilakukan pada usia lanjut yang ada di Panti Werdha Sukomoro Kota Palembang dalam rangka mencegah penyakit atau udaha dalam menskrining penyakit.

\section{METODE PELAKSANAAN}

Kegiatan pengabdian masyarakat ini dilaksanakan di aula Panti Werdha Sumarah Sukumoro Kota Palembang. Kegiatan dibagi menjadi 3 sesi,dimana sesi 1 dilakukan anamnesa atau pemeriksaan parameterfisiologis tubuh yaitu tekanan darah, dan kolesterol darah. Sesi ke-2, peserta PTM diberikan penjelasan tentang perilaku sedentary. Kegiatan ini dilakukan dengan melakukan kerjasama dengan para dosen keperawatan, analis kesehatan, dan pengurus Panti Werdha Sukomoro dalam penatalaksanaan pemeriksaan kolesterol. Kegiatan ini dilaksanakan pada bulan Januari 2021 dan diikuti oleh 31 peserta lansia Panti Werdha Sumarah, Palembang.

\section{HASIL DAN PEMBAHASAN}

Dari jumlah 31 peserta yang hadir, 51,60\% (16 peserta) berjenis kelamin perempuan, sedangkan 48.40\% (15 peserta) berjenis kelamin laki-laki. Terkait kategori usia, peserta yang hadir didominasi dengan usia lansia (>60 tahun) sebanyak 71,0\%, diikuti dengan usia pertengahan (23-37tahun) sebanyak 6,4\%, dan dewasa muda (40-59 tahun) 22.5\% (gambar 1). Data menunjukkan bahwa sebagian besar peserta yang hadir dalam rangka pemeriksaan kesehatan adalah perempuan dengan kualifikasi usia seperti pada gambar 2 .

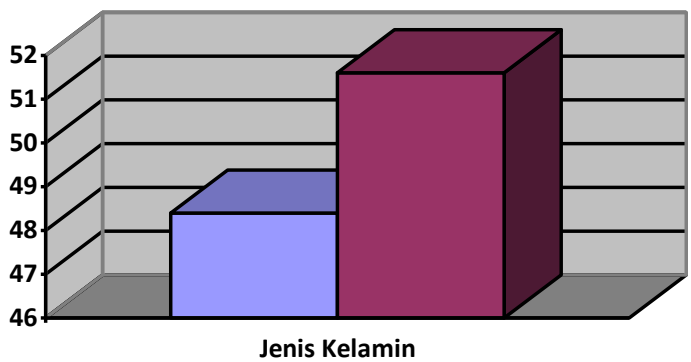

Gambar 1 Persentase peserta berdasarkan jenis kelamin 


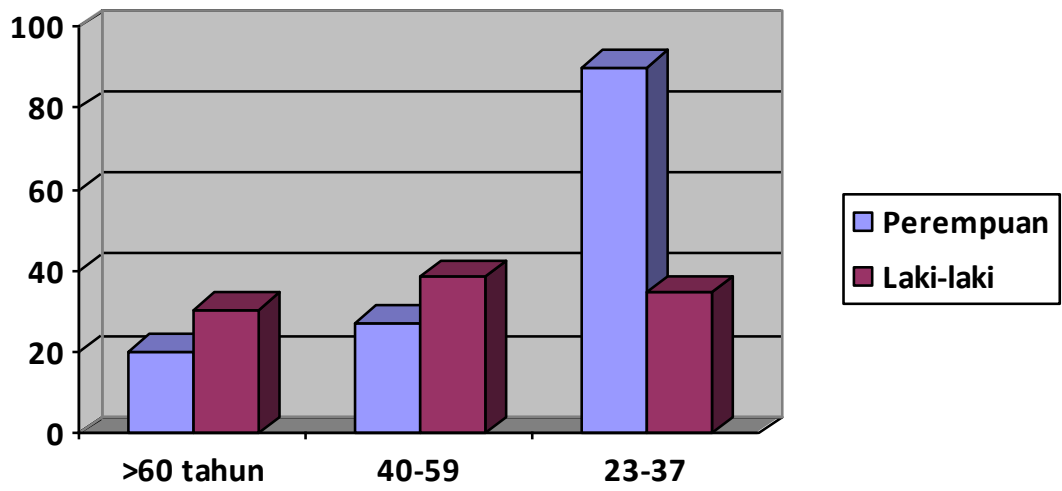

Gambar 2

Grafik klasifikasi usia dan jenis kelamin peserta

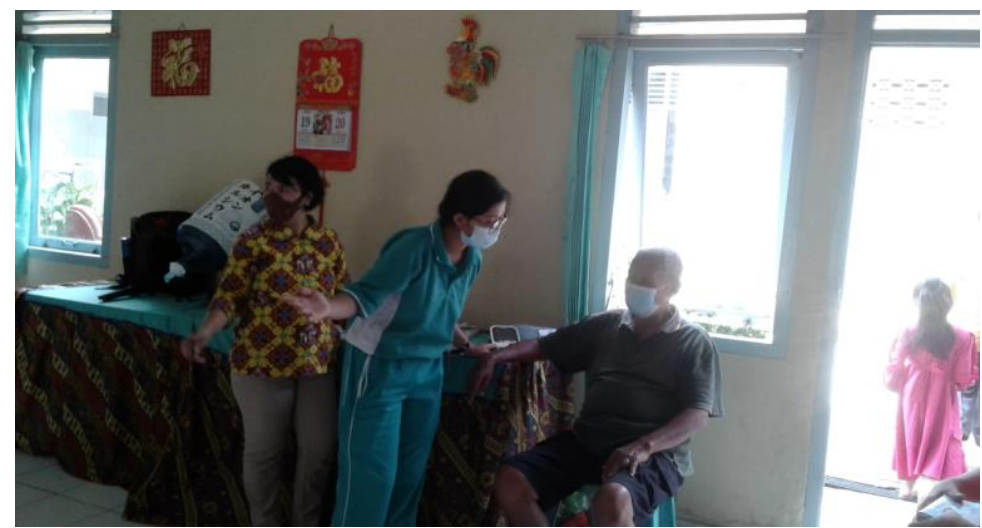

Gambar 3

Pengukuran Parameter fisiologis tubuh

Tabel 1

Hasi Pemeriksaan Parameter Fisiologi Peserta Prolansis

Parameter Fisiologi

n $\%$

Normal $(<120) \quad 7 \quad 23,3$

TD Sistolik

\begin{tabular}{lcc} 
Pre Hipertensi $(120-139)$ & 10 & 33,3 \\
\hline Hipertensi I $(140-159)$ & 7 & 20 \\
\hline Hipertensi II $(>160)$ & $\mathbf{6}$ & 23,3
\end{tabular}

TD Diastolik

\begin{tabular}{lcc} 
Normal & 10 & 33,3 \\
\hline Pre Hipertensi & 10 & 33.3 \\
\hline Hipertensi I & 6 & 20 \\
\hline Hipertensi II & 4 & 13,3
\end{tabular}

\begin{tabular}{llcc}
\hline Kadar Kolesterol & Normal & 14 & 45,16 \\
\cline { 2 - 4 } & Hiperkolesterolemia & 17 & 54,84 \\
\hline Total & & 31 & 100 \\
\hline
\end{tabular}

Data hasil pelaksanaa kegiatan PKM di Panti Werdha Sumarah Sukomoro menunjukkan bahwa dari 30 orang yang melalakukan pemeriksaaan darah kadar kolesterol 54,84 \% lebih dari normal ( > 200 $\mathrm{mg} / \mathrm{dl}$ ). Data hasil pemeriksaan tekanan darah oma dan opa penghuni Panti Jompo Sumarah Sukomoro 
menunjukkan adanya kecendrungan peningkatan tekanan darah seperti yanh termasuk kategori normal berjumlah 7 orang, prahypertensi berjumlah 10 orang, hypertensi tingkat 1 berjumlah 6 orang dan yang termasuk kategori hypertensi tingkat 2 berjumlah 7 orang.

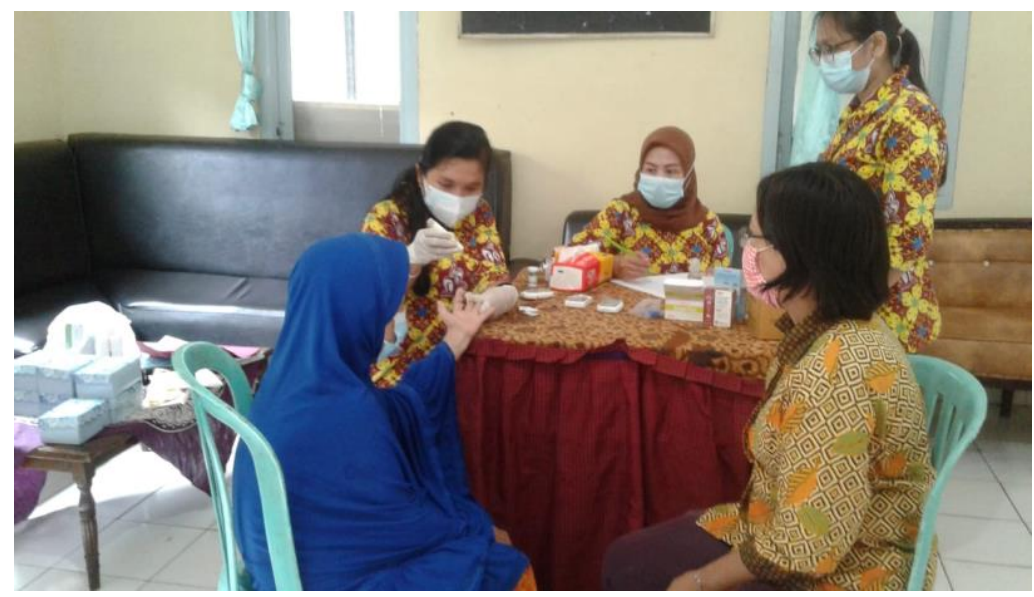

Gambar 4

Pemeriksaan Kolesterol

Darah mengandung $80 \%$ kolesterol yang diproduksi oleh tubuh sendiri dan $20 \%$ berasal dari makanan. Kolesterol yang ada di dalam darah berikatan dengan protein dan ditransporasi ke seluruh tubuh. Oleh karena itu kolesterol sangat penting bagi tubuh, namun bila kadar koleterol dalam darah berlebihan juga berbahaya bagi kesehatan (Botham and Mayes, 2006). Kadar kolesterol normal sekitar 140-200 mg/dL dan dikatakan kadar koleterol tinggi jika mencapai 200-400 mg/dL (Balai Informasi Teknologi LIPI, 2009). Lemak dan kolesterol tidak larut dalam cairan darah. Oleh karena itu agar dapat dikirim keseluruh tubuh, lemak dan koleterol harus dikemas bersamaan dengan protein menjadi partikel yang disebut lipoprotein. Lipoprotein dibagi menjadi 4 macam, yaitu Kilomikron, VLDL (Very Low Density Lipoprotein), LDL (Low Density Lipoprotein) kolesterol yang dikenal dengan lemak jahat, dan HDL (High Density Lipoprotein) yang disebut sebagai koleterol baik.

Kolesterol baik adalah lipoprotein dengan kandungan protein tinggi dan memiliki sedikit lemak yang dikenal dengan High Density Lipoprotein (HDL). HDL mengandung molekul anti oksidan yang dapat mencegah perubahan Low Density Lipoprotein (LDL) menjadi lipoprotein yang cenderung menyebabkan penyakit jantung (Putri, Hariyono and Sari, 2017). HDL berfungsi mencegah terjadinya penyimpanan lemak di dalam pembuluh darah, mengumpulkan kolesterol dari darah dan daerah yang terpengaruh ateriosklerosis dan membantu pembalikan proses sehingga dapat mencegah trombositosis (Anggraeni, 2016).

Pada umumnya bahan makanan yang mengandung kolesterol berasal dari organ binatang, terutama otak, kuning telur dan jeroan namun bahan makanan yang bersumber dari tumbuh-tumbuhan tidak mengandung kolesterol (Botham and Mayes, 2009). Bahan makanan yang mempengaruhi kadar HDL adalah asupan serat, dan gorengan. Asupan serat larut (soluble fiber) terdapat pada buah-buahan, sayuran, kacang-kacangan, biji-bijian, bulir utuh, dan oats dapat membantu menaikkan HDL darah.

Minyak jelantah memiliki ikatan asam lemak jenuh dan selama proses menggoreng, minyak akan mengalami perubahan komposisi asam lemak serta kualitas minyak (Rumah, Muji and Surabaya, 
2017). Ikatan asam lemak ini sulit diurai oleh tubuh dan terbawa dalam aliran darah dan akan mengendap pada pembuluh darah di jantung dan menyumbat aliran darah, sehingga dapat mengakibatkan peningkatan kadar kolesterol total, LDL(kolesterol jahat) dan trigliserida, serta penurunan kadar HDL (kolesterol baik) dalam darah. Sedangkan dengan mengkonsumsi makanan yang mengandung kadar kolesterol tinggi beresiko meningkatkan kadar kolesterol darah atau hiperkolesterolemia. Kenaikan kolesterol darah sangat berhubungan dengan terjadinya penyakit jantung (Anggraeni, 2016).

Dari hasil kegiatan pengabdian ini menunjukkan bahwa ada kecenderungan oma dan opa mengalami hypertensi dari 30 peserta hanya 7 orang dapat tekanan darahnya masih kategori normal. Solikin and Muradi, 2020, menjelaskan hipertensi meningkatkan risiko penyakit jantung dua kali dan meningkatkan risiko stroke delapan kali dibanding dengan orang yang tidak mengalami hipertensi. Selain itu hipertensi juga menyebabkan payah jantung, gangguan pada ginjal dan retinopati. Hal ini akan sangat membahayakan jika tidak dikontrol dengan baik. Nuradi, Jangga and Isma, 2019, menjelaskan Kadar kolesterol darah yang tinggi dapat mengakibatkan terjadinya endapan kolesterol dalam dinding pembuluh darah. Lama-kelamaan, jika endapan kolesterol bertambah akan menyumbat pembuluh nadi dan menganggu peredaran darah, sehingga memperberat kerja jantung dan secara tidak langsung memperparah hipertensi (Solikin dan Muradi, 2020).

Hypertensi merupakan salah satu penaykit Kardiovaskuler dan menurut hasil penelitian dari (Mamitoho, Sapulete and Pangemanan, 2016), senam bugar lansia yang dilakukan secara teratur dapat menurunkan kadar kolesterol darah pada lansia. Jika kadar kolesterol mengalami penurunan, itu sangat baik bagi tubuh karena dapat menghindarkan kita dari resiko penyakit kardiovaskular. Selain memperhatikan pola makan dan gaya hidup slah satu upaya untuk menjaga, meningkatkan kesehatan dan kesegaran jasmani bagi lansia adalah dengan melakukan olahraga. Kegiatan olahraga sangat bermanfaat bagi kesehatan manusia antara lain meningkatkan kerja dan fungsi jantung, paru dan pembuluh darah.

\section{SIMPULAN}

Berdasarkan hasil pemeriksaan penghuni Panti Werdha Sukomoro hasil pemeriksaan kadar kolesterol yang lebih dari normal berjumlah 17 orang $(56,66 \%)$ sedangkan hasil pengukuran tekanan darah dengan hasil lebih dari normal berjumlah 23 (76,6\%) artinya cukup banyak warga yang cenderung menderita hypertensi. Hal ini dapat disimpulkan bahwa kesadaran penghuni dan peneglola Panti Werdha Sumarah Sukomoro perlu ditingkatkan terhadap pentingnya pemeriksaan kesehatan dan seperti kolesterol, kontrol tekanan darah secara rutin mengatur pola makan, istirahat yang cukup dan lebih penting lagi adalah senam bugar lansia dilaksanakan secara rutin minimal setiap minggu dan jalan pagi atau exercise sesuai kemampuan setiap hari.

\section{UCAPAN TERIMA KASIH}

Ucapan terima kasih disampaikan kepada Romo Boni Pr, selaku penanggung jawab Panti Werdha Sumarah Sukomoro, Rektor, dan Dekan Universitas Katolik Musi Charitas yang ikut mendukung dalam pelaksanaan Pengabdian ini. 


\section{DAFTAR PUSTAKA}

Anggraeni, D. (2016) 'Kandungan Low Density Lipoprotein (LDL) dan High Density Lipoprotein (HDL) pada Kerang Darah (Anadara granosa) yang Tertangkap Nelayan Sedati, Sidoarjo', ADLN Perpustakaan Universitas Airlangga.

Balai Informasi Teknologi LIPI (2009) 'Kolesterol', UPT - Balai Informasi LIPI.

Botham, K. M. and Mayes, P. (2006) 'Sintesis, Transport dan Ekskresi Kolesterol', in Biokimia Harper. Botham, K. M. and Mayes, P. A. (2009) 'Sintesis, Transpor, \& Ekskresi KOlesterol', in Biokimia Harper. Ferdiansyah, D. (2016) 'Metode Pendekatan Keluarga, Terobosan Baru dalam Pembangunan Kesehatan di Indonesia', Farmasetika.com (Online). doi: 10.24198/farmasetika.v1i4.10368.

Kementerian Kesehatan RI (2016) Profil Penyakit Tidak Menular Tahun 2016, Journal of Chemical Information and Modeling.

Mamitoho, R. F., Sapulete, I. M. and Pangemanan, D. H. C. (2016) 'Pengaruh senam lansia terhadap kadar kolesterol total pada lansia di BPLU Senja Cerah Manado', Jurnal e-Biomedik. doi: 10.35790/ebm.4.1.2016.10845.

Nuradi, N., Jangga, J. and Isma, F. (2019)

PERBEDAAN KADAR KOLESTEROL DAN TRIGLISERIDA SERUM DARI DARAH YANG DIBEKUKAN SEBELUM DISENTRIFUS DAN YANG LANGSUNG DISENTRIFUS', Jurnal Media Analis Kesehatan. doi: 10.32382/mak.v10i2.1315.

Nuraeni, R., Akbar, M. R. and Tresnasari, C. (2019) 'Pengaruh Senam Lansia terhadap Tigkat Kebugaran Fisik pada Lansia Berdasar atas Uji Jalan 6 Menit', Jurnal Integrasi Kesehatan \& Sains. doi: 10.29313/jiks.v1i2.4633.

Putri, V. A., Hariyono, H. and Sari, E. P. (2017) ‘GAMBARAN KADAR KOLESTEROL TOTAL PADA LANSIA (Studi pada Posyandu Lansia Dusun Sumberwinong Desa Kedungpari Kecamatan Mojowarno Kabupaten Jombang)', Jurnal Insan Cendekia. doi: 10.35874/jic.v3i2.279.

Rumah, ), Muji, S. and Surabaya, R. (2017) 'ANALISA GLUKOSA DARAH ACAK DAN KOLESTEROL PADA PASIEN OBESITAS DENGAN USIA 20-30 TAHUN DI DESA KABUNAN KAB. BOJONEGORO Ainul Yaqin *), Itsna Lutfia Nur Fadila', Jurnal Sains.

Sarasawati, S. Y. (2020) 'Kadar Kolesterol Total Pada Perokok Aktif Dan Perokok Pasif', STIKes Insan Cendekia Medika Jombang.

Solikin, S. and Muradi, M. (2020) 'HUBUNGAN KADAR KOLESTEROL DENGAN DERAJAT HIPERTENSI PADA PASIEN HIPERTENSI DI PUSKESMAS SUNGAI JINGAH', JURNAL KEPERAWATAN SUAKA INSAN (JKSI). doi: 10.51143/jksi.v5i1.230.

WHO. 2011. Global status report on non- communicable diseases. Diambil darihttp://www.who.int/nmh/publicati ons/ncd_report_full_en.pdf

Yusfita, L. Y. 2018. Hubungan Perilaku Sedentari Dengan Sindrom Metabolik Pada Pekerja. The Indonesian Journal of Public Health , 143-155.

World Health Organization. 2018. Noncommunicable diseases country profiles 2018. 